\title{
Philo of Stockholm The Ecumenical Heresies of Rabbi Marcus Ehrenpreis
}

\author{
GöRan Rosenberg
}

DOI: https://doi.org/10.30752/nj.86971

\begin{abstract}
This paper was presented at the conference 'The Marrano Phenomenon: Jewish Hidden Tradition and Modernity', Warsaw, I6-19 September 2019. It considers the case of Marcus Ehrenpreis, chief rabbi of Stockholm (I9I4-48). Ehrenpreis followed in the tradition from Antiquity of Philo of Alexandria, who expressed his Jewish philosophy in Greek, and Moses Mendelssohn, who attempted to bring the principles of the Englightenment to German Jews and to promote an understanding of Judaism among non-Jews. Ehrenpreis sought to follow a similar path among the Swedes, not least in making Swedish his preferred language of writing. Although the Marrano phenomenon relates primarily to the concept of 'borderline'Jewishness, of which Ehrenpreis was not an exponent, it nonetheless proves fruitful to consider him from a Marrano perspective in order to extend our understanding of him as an innovative figure who sought to achieve greater understanding across the religious and cultural boundaries between Judaism and non-Judaism.
\end{abstract}

\section{A rabbi as a Marrano?}

Can the notion of the Marrano be extended to encompass a fully fledged and serving rabbi, making no secret of his Jewish premises? In this talk, I will argue that in the case of Dr Marcus Ehrenpreis, the grand rabbi of Bulgaria, I900-I4, and the chief rabbi of Stockholm, I9I4-48, this notion may indeed be a fruitful way of defining and understanding at least a part of his thought and actions. Although it is true that in the context of this conference the Marrano phenomenon has been defined as the presence of a 'borderline Jewish identity which avoids clear-cut cultural and religious attribution', I will try to show that a somewhat similar identity might also be assumed by a person deeply steeped in the Jewish tradition and with a strong public commitment to the revitalisation and strengthening of the role of Judaism in the world.

I must first admit that I would not have thought of bringing my rabbi into this philosophical Marrano fold of mostly 'non-Jewish' Jews, betraying their Jewish affinities only in various subtle and subterraneous ways. However, after putting on the Marrano glasses generously handed to me by Agata Bielik-Robson and her fellow 'marranistas', there, lo and behold, I was able to see not only a fully fledged and serving rabbi with a straight-forward affiliation to Judaism, but also a Jewish writer and thinker who at times resorted to subtle and subterraneous ways to disseminate what he believed were significant Jewish tenets and ideas into a world all too ready to defame and denigrate 


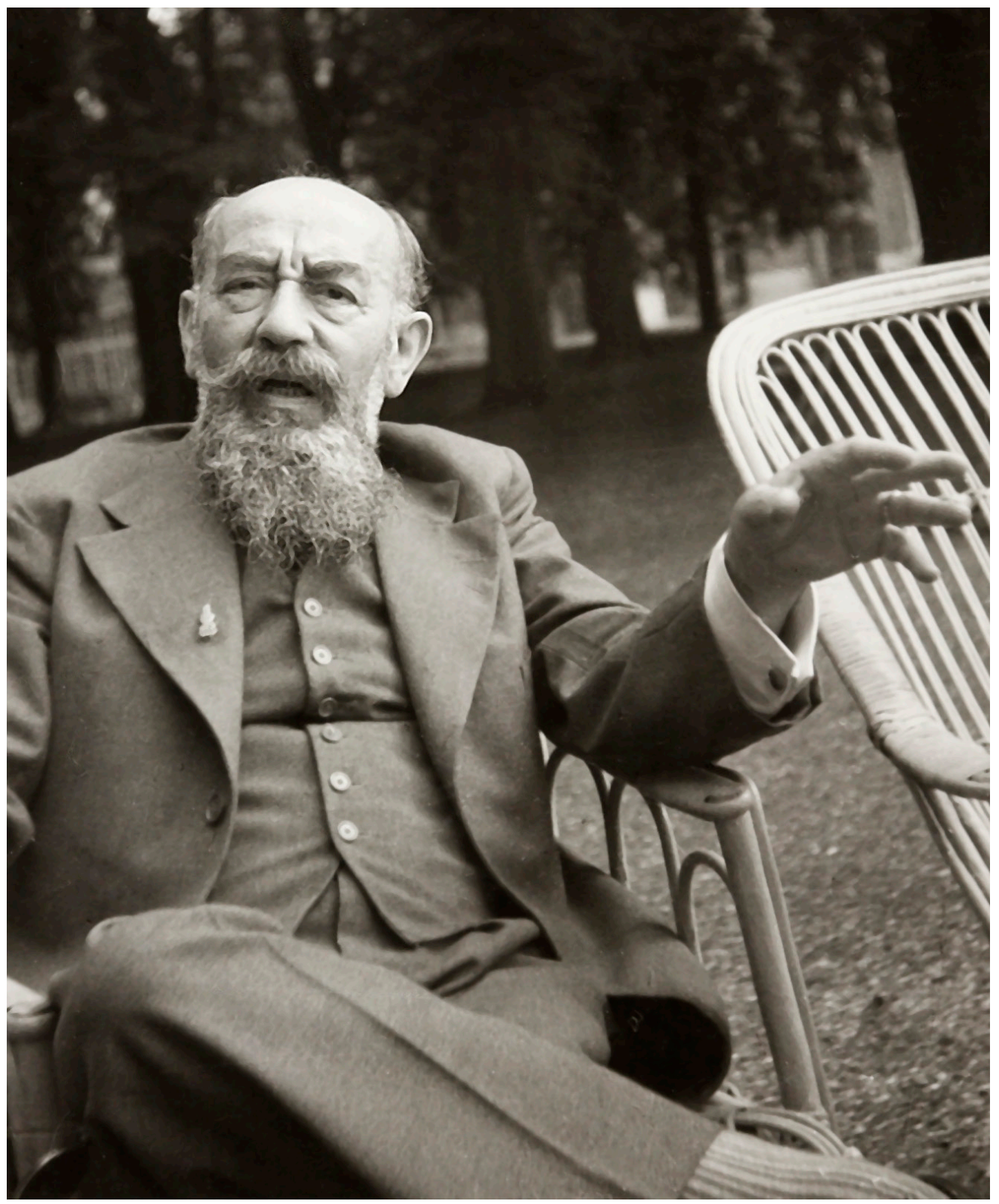

Marcus Ehrenpreis, photographed by Anna Riwkin.

Source: The Anna Riwkin Collection, Moderna museet, Stockholm.

anything Jewish. Or more precisely, what I encountered were his considerable efforts in making a wholly new language, Swedish, his preferred language of writing and sermoning, while developing a somewhat heretical ecumenical view of the relationship between Judaism and Christianity, arguing for a common return to the heritage of the Hebrew prophets in confronting a world of growing spiritual wilderness and moral disarray. 


\section{Who was Marcus Ehrenpreis?}

Marcus (or Mordechai) Ehrenpreis was born in I869 in what was then Lemberg in the province of Galicia in the Austro-Hungarian Empire. The languages of his home were Yiddish and Hebrew, the languages of his city were also German and Polish, the languages of his future walks of life were Croatian, Bulgarian, JudaeoHispanic and Swedish, and he learnt to master them all. He had a genius for language, one could say, which is of some relevance in the context of this presentation.

More importantly, perhaps, the small circle in which Ehrenpreis developed his early views of Judaism and the world was made up of young men (no women in sight) with a similar background: they had strong emotional and religious ties to traditional Judaism on the one hand, and an equally strong urge to have Judaism make its voice heard in the world of German Bildung, on the other. ${ }^{1}$

Although this was certainly a generation with strong enlightening ambitions for Judaism, it was also one to which the shortcomings and failures of the earlier Jewish enlightenment, the Haskala, had become apparent. Not only had it largely failed to communicate the lasting values and virtues of Judaism to modern Christians, but it had also failed to do so to modernising Jews as well. It had bent over to make Judaism more understood and appreciated by fellow Germans and Poles, but it had done so by diminishing its Hebrew soul and thereby obscuring its universal spirit. These were men who firmly believed that Judaism, properly expressed on its own terms and in its own language, Hebrew, could have an important

1 Ehrenpreis saw the German ideal of Bildung, as well as the Swedish ideal of folkbildning, adult popular education, as a means by which a harmonious, modern Jew could be fostered in a dialectical relationship with European culture as a whole (see Fruitman 200I, 82 ff.). role to play in an emerging Europe of spiritual confusion, nationalist awakening and cultural creativity. They wished to revitalise Judaism by affirming its own religious and cultural tenets and not by accommodating it to the tenets of European Bildung. They wished for a Judaism that would be able to change Europe as much as it would be changed by it.

\section{A Judaism with a mission}

They were not the only ones thinking about the future of Judaism, of course. This was a time when the Jews of Europe were continuously being supplied with new and often ominous reasons to contemplate their existence. And many of them famously did. Suffice to name a few of those with whom Ehrenpreis came into early and close contact: in addition to Theodor Herzl, there was, notably, Ahad Ha'am, the founder of what was to be called cultural Zionism, as distinct from political Zionism - the idea of Palestine as a centre for a Jewish spiritual and cultural renaissance rather than a territorial refuge; there was also Martin Buber, some ten years younger, with whom Ehrenpreis came to share many of his ideas regarding the nature of such a renaissance; also those still unrecognised poets and novelists who were making Hebrew their chosen language of literary expression and exploration, and at the end of the day the language of the radical Jewish cultural and spiritual renaissance which they were all groping for - here we come across the names of Josef Berdyczewski, Shaul Tchernichowsky and Chaim Nahman Bialik, all sharing more or less the same background, all straddling the same dissolving walls between yeshiva and university, shtetl and cosmopolis, all hoping to construct a two-way passage between them.

\section{A new language}

Seventeen years later, at the time of his arrival in Sweden in September 19I4, after fourteen years 
as the grand rabbi, chachambashi, of Bulgaria, Ehrenpreis would still remain a latter-day child of the ghetto, and he would still believe in the power of language and literature to bring about a new synthesis between Judaism and the world. What would not remain, however, was Hebrew as his chosen language. The language at the centre of his Jewish endeavours was henceforth to be Swedish, not Hebrew. His subsequent books, essays, articles and sermons were primarily to be aimed at a Swedish audience,Jews and non-Jews alike, and only in translation would the bulk of his literary production be available to the world at large. This would seem a betrayal of sorts of the Hebraist movement, making Swedish, and not Hebrew, his language of prophecy and preaching, or more prosaically, the language in which he would come to express his views of the world and his visions of Judaism, and in which he would become a renowned literary and cultural personality in his own right.

One might have assumed that this was a choice of necessity; the chief rabbi of Stockholm must first of all make himself understood in his own constituency. Yet in the case of Marcus Ehrenpreis necessity quickly became embedded in a credo, an expressed belief in the transformative power of any language, even Swedish, to bridge the gap between modernising Jews and Judaism, and between Judaism and the modernising world.

In any case, with his arrival in Stockholm, the scene was set for a unique experiment in European Jewish revival. Was it possible to transform a largely dormant and rapidly assimilating Jewish community on the periphery of Europe into a self-confident force for cultural and spiritual exchange? Could the Jews of Sweden be brought to embrace the richness and relevance of their own heritage, and could non-Jews be brought to understand that a spiritually revitalised Judaism had something to contribute for them as well?
In many ways, this was what Moses Mendelssohn had hoped to achieve when he set out to bring the culture of enlightenment to the Jews of Germany, while at the same time bringing the ideas and values of Judaism to a German culture still impregnated with anti-Jewish tropes and traditions. ${ }^{2}$

However, being a philosopher of that same enlightenment, firmly believing in the power of reason to change minds, the task Mendelssohn set for himself was to demonstrate that Judaism was as reasoned and rational a religion as Christianity, in certain respects perhaps even more so, and in any case fully compatible with an enlightened society: Judaism was not an obscure and obsolete religion superseded by Christianity, but a living tradition with its own distinctive role to play in the moral universe of humankind. The enlightened society of Moses Mendelssohn was one in which religious pluralism would be the natural corollary to the inherent right of the individual to freely examine and express his or her own beliefs and judgements. ${ }^{3}$

Mendelssohn as a philosopher was convinced that reasoned argument would carry the day, and he aimed at the mind rather than the heart, but he was, of course, soon to be bogged down by the most unreasonable and heartless recriminations for not disavowing his own reasoned beliefs and judgements.

At the time of Ehrenpreis and the Young Hebraists, the heartlessness of the arguments had only increased, and with the emergence of

2 By translating the Hebrew Bible into German (with Hebrew letters) Mendelssohn hoped to 'render a service to my children and perhaps to a considerable part of my nation [...]. This is the first step towards culture, from which my nation, alas, is being kept at such a great distance.' (From a letter to August Hennings, 29 June $\mathrm{I} 779$, quoted in Kalimi and Haas 2006, 193.)

3 'Neither church nor state has a right to subject men's principles and convictions to any coercion whatsoever'(Mendelsohn I983, 70). 
'modern' antisemitism reason had gone even further out of the window, and it had become all but clear that the road of enlightenment was becoming a trap, or a cul-de-sac, at least for those who wished to see a revitalised and relevant Judaism emerge from it, and not a humiliated, depleted and despised remnant. Not to mention, God forbid, a Judaism with no remnants at all.

This was, then, a time for Jewish self-reflection and re-evaluation, opening up a wholly new landscape of Jewish hopes and anxieties, giving rise to a new set of Jewish movements and ideologies, most of them in reaction to circumstances where the tenets of nation and history, language and culture, roots and race, Blut und Boden, were replacing the tenets of enlightened reason and individual citizenship as the markers of identity and belonging.

\section{A Romantic turn}

This is the background against which I believe we must understand the position of Ehrenpreis at the time of his arrival in Sweden. Where Moses Mendelssohn had hoped to reach the reasoned minds of his contemporaries, Ehrenpreis and his generation were left to grope for their hearts. The language of religion, literature and poetry were to be means of communication as important as the language of politics and philosophy, bringing about an era of spiritual enlightenment during which the values and ideals of Judaism would again be brought to resonate with the world.

One could perhaps describe this as a romantic turn of the Mendelssohn project, forgoing the rationality of Judaism for its spirituality, its adaptability for its authenticity. In the case of Ehrenpreis it can also be described as a messianic turn, linking the spiritual renaissance of Israel to a coming era of universal peace, tolerance and understanding.

This was the time of a spiritual reawakening within Judaism, a new Exodus, a new dawn, of Israel rediscovering the path to its own sources (cf. Ehrenpreis 1928a, 45-8). He would henceforth devote most of his writings to the exploration and promulgation of the Hebrew legacy, its prophets and sages, its literature and poetry, aiming to demonstrate that the distinct particularities of Judaism were part and parcel of its universal significance.

The fact that Ehrenpreis chose to do so in a language completely new to him, of very limited universal significance, with no expectations of being read and understood by more than a minute fraction of the Jews of Europe, not to speak of its non-Jews, must at first have been seen as an abandonment, a radical retreat from the lofty barricades of the Young Hebraists and the Cultural Zionists, an all-too pragmatic accommodation of ideals to circumstances. How could it be that a man who had considered the revival of Hebrew the sine qua non for the revival of Judaism would suddenly reject Hebrew in favour of Swedish?

Whatever the pragmatic reason for such a move, Ehrenpreis would soon make it a matter of principle, in fact making it central to his vision for a Jewish renaissance. Although a self-declared Cultural Zionist in the vein of Ahad Ha' am, aiming for the establishment of a Jewish spiritual centre in Palestine, he was convinced that Judaism must flourish in a dynamic exchange with the world. A recurrent theme in his writings would be the 'happy' meetings between 'Israel and the peoples', meetings in which Judaism had come into contact with the world and the world with Judaism. ${ }^{4}$

A recurrent feature of these meetings, Ehrenpreis emphasised, had been the transformation of host languages into Jewish

4 In his book Israels möten med folken ('Israel's Meetings with the Nations') from 1934, Ehrenpreis explores five such 'meetings' Babylon, Hellas, Christianity, Islam and the West. 


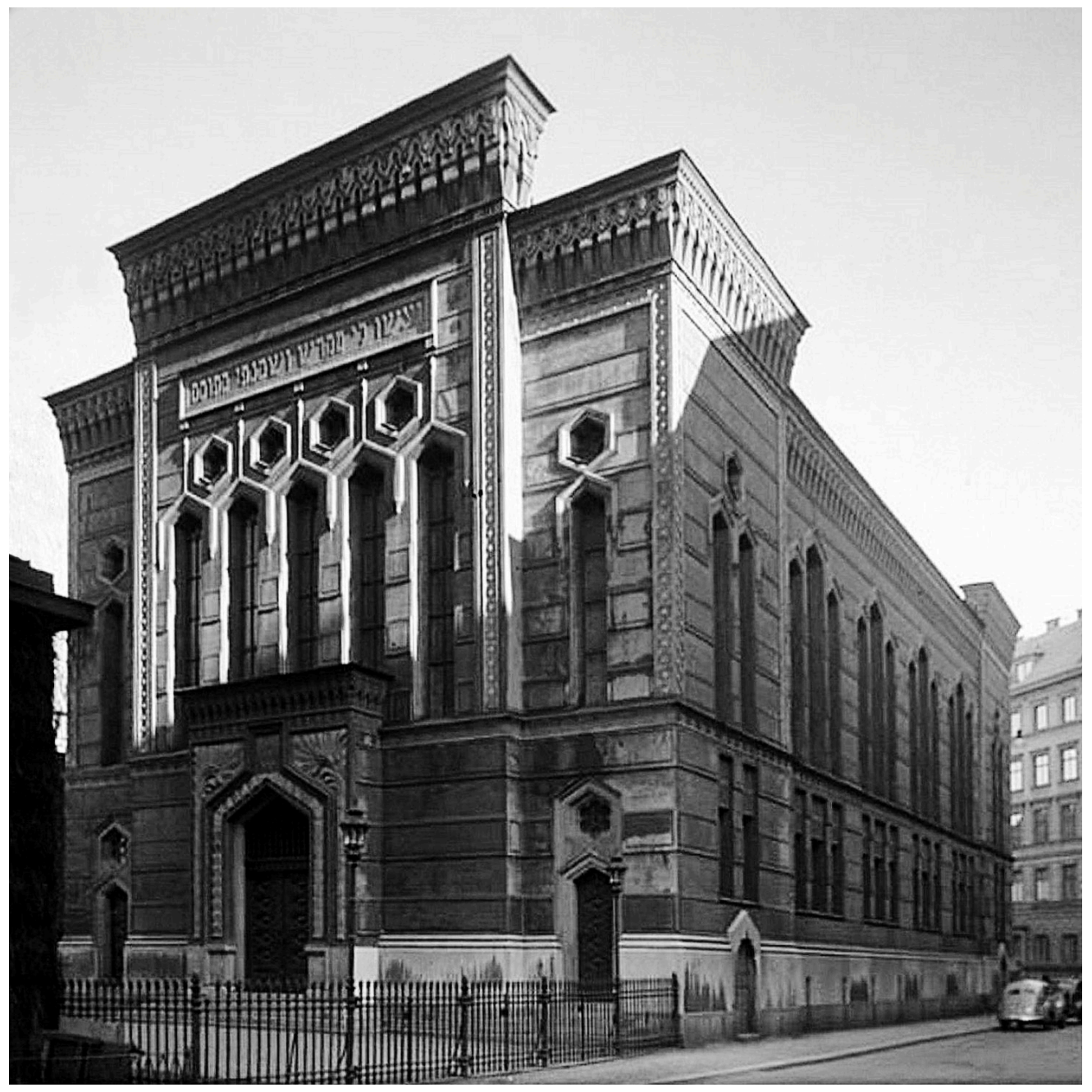

The Great Synagogue of Stockholm, photographed in 1942 by Lennart af Petersén. Source: Stockholm City Museum.

vernaculars, creating Hebraicised forms of Aramaic, Greek, Arabic, Spanish and German, making for the evolution of wholly new Jewish languages. These languages were certainly formed and characterised by the surrounding majority languages, but as they increasingly became means for the literary expression of Jewish thoughts and experiences, they also came to leave 'a mark of the Jewish cultural spirit' on those languages themselves (Ehrenpreis 1935, 203). Moreover, Ehrenpreis argued, this synthesis between the spirit and language of Judaism and the spirit and language of the foreign cultures in which the Jews resided must remain at the very the foundation of Jewish life in the Diaspora. He would term this dynamic relationship either 'cultural dualism' or 'synthetic assimilation', by which he meant a mode of coexistence in which a people remained faithful to its roots and cultivated its own spiritual and cultural values, while remaining open to what was sound, good and noble in the host culture, assimilating it into its own spirituality (Ehrenpreis I934, 57). 
According to Ehrenpreis, the exemplary Jewish thinker and leader in this regard was Philo of Alexandria (c. $20 \mathrm{BCE}-c .5 \mathrm{O} \mathrm{CE}$ ), whom he credited for initiating the very process of cultural dualism by expressing his Jewish philosophical system in Greek, thereby bringing the spirit of Judaism to the Hellenic world as a whole, Greeks and Jews alike (made possible by the translation into Greek of the Hebrew Bible, the Septuagint). In this way, according to Ehrenpreis, Judaism managed to serve as a 'spiritual corrective to disintegrative cultural assimilation' in the Hellenistic world (ibid., 66). Multilingualism was not a hindrance to the spiritual development of Judaism, but rather a condition for it. A Jewish literature written in Diaspora languages was the chief means of restoring a sense of pride and dignity among the Jews of the Diaspora while enabling them to engage in a fruitful dialogue with their non-Jewish cultural environment. From this perspective there was no difference between Alexandria and Stockholm. Ehrenpreis's radical immersion, at the age of forty-five, in the language and literature of yet another foreign culture might then best be understood as a manifest expression of his determination to make Sweden an example of Philo's synthetic assimilation.

\section{Philo of Stockholm}

Ehrenpreis was a linguistic genius, no doubt, and as he had already mastered Croatian and Bulgarian and Judaeo-Hispanic along the road, he would soon make Swedish his language of preaching, teaching and writing, within a few years producing what was possibly the first translation of modern Hebrew poetry into any European language (Ehrenpreis and Josephson I920). From now on a steady stream of Jewish topics expressed by Jewish writers and thinkers would be introduced into of the realm of the Swedish language. Ehrenpreis himself soon became a prominent cultural figure on the Swedish cultural scene, producing a series of widely acclaimed books, founding a highquality Jewish magazine, Judisk Tidskrift, publishing a wide array of essays and commentaries on Jewish matters, translating and interpreting old and new Jewish texts, contributing to a surge in Swedish-Jewish cultural and educational activities and inspiring leading Swedish cultural personalities to take an interest in Jewish ideas and values.

In a speech in Tel Aviv in 1935, celebrating the tenth anniversary of the Hebrew University, Ehrenpreis felt obliged to defend his resorting to Swedish, proudly informing his audience of mostly ardent Hebraists that 'everyone in Sweden could now familiarise themselves with the essence and spiritual values of Judaism' (Ehrenpreis I935, 2IO-II).

Making the values of Judaism better known to the world would be a way of countering the Pharaonic or Teutonic values that he now perceived were about to destroy not only Judaism but the Western Christian civilisation with it. 'For centuries we have lived among the nations and with the nations, but the world does not know us', he laments in 1934, implying that if the nations only would know, things might turn out differently (Ehrenpreis I934, I98).

Not surprisingly then, what Ehrenpreis, with increasing urgency, wants the nations to know, and what at least the Swedish people must be given a chance to know, is the continued relevance of Jewish texts, tenets and traditions to the ideas of universal peace, justice and brotherhood.

Ehrenpreis's strand of cultural Zionism thus evolves into a diasporic mission, a striving for the revival of the Jewish spirit and the renaissance of the Jewish people among the gentiles, paving the way for 'a messianic humanity' and the pursuit of 'the true Zion'.

The Judaism of Marcus Ehrenpreis is a Judaism able to fulfil its messianic task only in a cultural and spiritual exchange with the 
peoples of the world and reinforced and inspired by the rebirth of a cultural and spiritual centre in Zion.

\section{Subtle and subterraneous ways}

It must be emphasised that in no way did Ehrenpreis hide his Jewish intentions or ambitions, nor did he advocate the accommodation of Judaism to assimilationist pressures and temptations. However, he also had a deeply rooted faith in the power of language and literature in transforming the relationship between Judaism and the world, and thereby transforming the world itself, and in his own writings he developed a specific skill in rendering Jewish texts and ideas in a language and form that made them appear less Jewish and more universal in kind. In a remarkably short span of time, he managed to become recognised as a Swedish writer and intellectual in his own right, with a keen linguistic and literary ability to attach a familiar Swedish ring even to the most Jewish of topics and themes.

In his major Swedish work, a trilogy of books on the prophets, sages, poets and heroes 'that built Israel' (Ehrenpreis I929, I93I, I943), he effectively mixed fictional accounts and anecdotes with quotations from original texts and sources, making the various protagonists of Judaism into free-thinking contemporary interlocutors. Not only did he make them speak the language of contemporary Swedes, but he made them appear human, familiar and culturally relevant, thereby hoping to bring out 'the true face' of Judaism across deeply embedded layers of anti-Judaism in the surrounding cultural landscape. Or as he wrote in 1935, defending his decision to become a Swedish writer: 'Our true face is hidden. Our spirit is maligned. Our teachings are falsified' (Ehrenpreis 1935, 2II).

In one typical story, Ehrenpreis has Gamaliel, the son of Hillel, meet his contemporary, Saul from Tarsus, who has now become Paul, the leader of the Nazarenes, a new messianic Jewish movement with universal ambitions. Gamaliel is mentioned in Acts as a respected Pharisee and a 'teacher of the law' who defended the Apostles in the court of Sanhedrin (Acts 5: 34), and as the teacher of Paul himself 'in the law of our ancestors' (Acts 22: 3). In Ehrenpreis's rendering of history, Gamaliel meets his former student as he is brought in chains to the Jewish High Court to be tried and sentenced as an agitator. In the fictitious events and conversations that unfold Ehrenpreis manages to demonstrate that the Nazarene movement was an inherently Jewish movement, that Saul or Paul was a figure wholly within the fold of Pharisaic Judaism, and not least, that Gamaliel represented the true face of post-biblical Judaism. Ehrenpreis has him advocate not only tolerance and leniency towards the Nazarenes in general and the accused Paul in particular, but has him also expressing sympathy for the man who has been proclaimed as the Messiah, Jeshua from Nazareth, saying of him: 'Jeshua did not fight against the teachings of the Pharisees, he fought against Pharisean men who did not act as they taught' (Ehrenpreis I93I, 9I). As Paul requests a meeting with his former teacher, a dialogue takes place in which Gamaliel has Paul come out as a high-handed distorter of his own master. 'The piety of Jeshua', Gamaliel says, 'is grown from the same soil as that of the Pharisees, from the Torah and the Prophets' (ibid. I3I). Thus, pitting Jesus from Nazareth against his apostle, Ehrenpreis aims to show that the separation between Judaism and Christianity had no ground in the teachings of Jesus himself, but in the anti-Jewish distortions that were perpetrated by Paul and his followers. The true face of Judaism was a face that good Christians would recognise if they were allowed to see it, and in order for them to see it, subtle and subterraneous means were necessary. 
When Ehrenpreis's first full-length book in Swedish, Österlandets själ (The Soul of the East), was published in I926, it was hailed as a literary sensation. One critic compared him to Joseph Conrad in his literary mastery of a foreign language, and a renowned writer and member of the Swedish Academy, Fredrik Böök, wrote that 'the pathos and the poetry of his words glow from the beauty of biblical texts. To the Swedish reader this book is at once an exotic stranger from the East and an intimate friend from your childhood'(Böök I926). And yet another critic wrote: 'A deeply religious and Jewish book that ought to be enjoyed by everyone, independent of nation and religion' ('Nbg' in Dagens Nyheter, 2I November 1926).

In addition, the book became a bestseller. It was printed in several editions and sold in thousands of copies, and very soon rabbi Ehrenpreis was touring small towns in the Swedish countryside, giving lectures to a workers' study circle in Sandviken, a seaman's church in Gävle, the International Women's Association for Peace and Freedom in Ystad, the Department of Divinity at Uppsala University, the Philosophy Club at the University of Lund, and the Sixth International Conference of Historians in Oslo in August of 1928.

He also began a tradition of delivering sermons on Sundays in the beautiful nineteenthcentury synagogue of Norrköping, I40 km south of Stockholm, with mostly non-Jews attending.

\section{An ecumenical heresy}

In 1928 Ehrenpreis embarked on his most ambitious effort to bring the Swedish society into contact with 'the true face' of Judaism, in the form of a monthly magazine in Swedish, Judisk Tidskrift. It was a remarkable achievement in scope and quality, and for three decades it was to serve as the intellectual and literary platform for that meeting between 'Israel and the peoples' that Ehrenpreis so urgently wished to bring about.
The very first article - 'The Idea of Peace in Judaism' - in the first issue set the tone for Ehrenpreis's venture. Here Ehrenpreis again stressed the necessity of building a bridge between the people of Israel and the world, not only for the sake of Israel but for the sake of the world. The idea of brotherly peace between nations had originated in Judaism and Judaism still had an important contribution to make. 'No peace is conceivable as long as religions are at war with each other', he wrote. And putting his words in the mouth of his favourite prophet, Micah, he proposed the creation of a League of Religions to fight the common enemy; a godless, materialistic and demoralised world, prone to war, persecution and the rule of force (Ehrenpreis I928b, 4 ).

For a Jewish rabbi to be a proponent of radical ecumenism, encompassing not only Christianity but Judaism as well, was not only unusual at the time, but could be perceived as heretical as well. At least, it could be seen as an accommodation of Judaism to the pressures of the time. But in the eyes of Ehrenpreis, this was not the accommodation of Judaism to Christianity, but rather the other way around, a rediscovery by the Christian world of its Jewish roots, and of the continued relevance of these Jewish roots in confronting its own growing spiritual crisis.

While the Marrano phenomenon in the context of this conference may be defined as the veiled or hidden presence of Jewish tropes and thoughts in and among people with few or no admitted ties to Judaism, it might also be made to comprise a literary reformulation and redressing of Jewish tropes and thoughts, in order to have them appear, if not less Jewish, then less conformist to anti-Jewish biases and stereotypes, and thus better suited to being able to seep into the consciousness of the world and change it; or more precisely, in the case of Ehrenpreis, to bring about a messianic turn in the course of events. With the world 
descending into a moral abyss, as he saw it, with the forces of materialism vanquishing the spirit of humanity, with the threat of war and destruction persistently looming on the horizon, a new meeting between Israel and the peoples might herald a new era of universal peace and understanding.

He was encouraged in his radical ecumenical stance by what he envisioned to be the reemergence of Jerusalem as a cultural and spiritual centre of Judaism, thereby enabling Israel to fully assume its spiritual role in the world. Or, to quote Hermann Cohen, his fatherly mentor at the Hochschule für Wissenschaft des Judentums in Berlin whom he liked to cite: 'Israel is carrying the fate of God on its shoulders'.

His brand of cultural Zionism, little understood and appreciated by his politically nationalist Zionist colleagues and friends, was then largely a diasporic Zionism, in which the existence of Israel as a spiritual nation among the nations remained the raison d'être of Judaism. Or, as he insisted in a public debate in March 1945, when the destruction of the European Jewry was there for all to see: 'We are not a nation because we have a common enemy. We have enemies because we are not a nation like all the others' (Ehrenpreis and Valentin 1945). With all his support for and admiration of the political Zionist project, Ehrenpreis could never let go of the nation-transcending quality of Jewish existence.

\section{Ehrenpreis and the Marranos}

History has since long given short shrift to the ideas and actions of Rabbi Marcus Ehrenpreis, and whether they had a Marrano quality to them or not is a question that has been raised only because I was inspired to do so as his ardent biographer, to see whether, by putting on a pair of Marrano glasses, I would see something that was not visible to me before. Admittedly, I had to stretch the notion a little to be able to see that hidden or subterraneous aspect of Ehrenpreis's Jewish enterprise: but there I saw it nonetheless.

What I then also saw in a new light was his manifest interest in the Marrano phenomenon itself. During a journey to Spain and Portugal in the summer of 1927 , he eagerly documented the continued presence of a distinct Marrano identity in parts of Portugal, with people preserving fully recognisable Jewish traits and traditions. He visited Marrano families and recorded Marrano prayers and met with a newly emerged and deeply committed Marrano leader, an army captain by the name of Arthur de Barros Bastos. He came to see the Marrano phenomenon as a testimony to the enduring power of the Jewish spirit, as well as to the futility of religious coercion and oppression. 'The remarkable story of the Marranos tells us that true religion is inseparable from freedom and tolerance' (Ehrenpreis I927, 95). Long after the murderous flames at the stakes of the inquisition had gone out, the Marranos lived on, appearing in the eyes of Ehrenpreis 'as a historical incarnation of that thorn bush [the appearance of God on Mount Sinai] which burnt without being consumed' (ibid.).

The Marrano phenomenon also spoke to his sense of Judaism as an increasingly personal choice and undertaking, giving rise to new questions on how to be a Jew and why. The most pressing question for his generation, Ehrenpreis argued, was how to be a fullfledged participant in the life and culture of the nation in which you lived and still stay true to your Jewish heritage. Ehrenpreis thereby draws a line from Elisa ben Abuja, the famous or infamous Acher of the Talmud, who was beset by doubts and literally stretched the borders of Judaism, to Baruch Spinoza, who emphatically crossed them, while both of them somehow remained true to their Jewish spiritual heritage. On Spinoza he wrote that he came to realise 'one of the most essential elements in 
Judaism - the longing for God and the striving to understand the divine, and in this he was a Jew in the best sense of the word' (Ehrenpreis I932, 238). Or as we might say in this context, a Marrano of the highest degree.

The case of Ehrenpreis was very different, of course, with no borders openly crossed, but in his literary endeavour to finesse the face of Judaism so that it might touch the world and change it, he was perhaps a Marrano character after all, albeit in reverse, exhibiting a clear-cut Jewish identity but at the same time endowed with the skill and determination to surmount cultural and religious boundaries.

\section{References}

Böök, Fredrik, 1926. 'Österland och Västerland', Svenska Dagbladet, 23 November 1926.

Ehrenpreis, Marcus, 1926. Österlandets själ [The Soul of the East]. (Stockholm, Geber)

— 1927. Landet mellan öster och väster [The Land between East and West] (Stockholm, Geber).

— I928a. 'Yttre och inre frihet', Judisk Tidskrift, 2, pp. 45-8.

— I928b. 'Fredstanken i Judendomen', Judisk Tidskrift, I(I), pp. I-5.

— 1929. Profeter och Gudsmän [The Prophets and the Pious] (Stockholm, Geber).

— I93r. Heliga och hjältar [The Holy and the Heroes] (Stockholm, Geber).

— I932. 'Den personliga judefrågan', Judisk Tidskrift, 8, pp. 233-4I.

— 1934. Israels möten med folken [Israel's Meetings with the Nations] (Stockholm, Geber).
— 1935. 'Hur jag blev svensk författare', Judisk Tidskrift, 7, pp. 20I-II.

—1943. Skalder och siare [Poets and Visionaries] (Stockholm, Bonnier).

— and Ragnar Josephson, 1920. Nyhebreisk lyrik I870-1920 (Stockholm, Norstedt).

— and Hugo Valentin, I945. 'Palestina och diaspora, offentligt samtal mellan M. Ehrenpreis och H. Valentin', Judisk Tidskrift, 6, p. I63-7I.

Fruitman, Stephen, 200I. Creating a New Heart. Marcus Ebrenpreis on Jewry and Judaism, Idéhistoriska skrifter 35 (University of Umeå, Department of Historical Studies).

Kalimi, Isaac, and Peter J. Haas, 2006. Biblical Interpretation in Judaism and Christianity (London, Bloomsbury).

Mendelsohn, Moses, I983.Jerusalem, or On Religious Power and Judaism, trans. Allan Arkush (Waltham, MA, Brandeis University Press).

Nbg 1926. 'Mänsklighetens barnkammare', Dagens Nyheter, 2I November 1926.

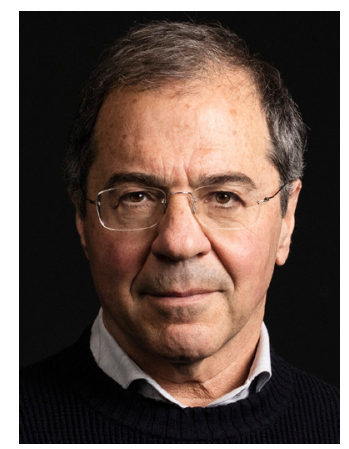

Göran Rosenberg is a Swedish journalist and author. He is currently working on a biography of Marcus Ehrenpreis. 